\title{
MELEMAHNYA EKONOMI INDONESIA PADA SEKTOR PARIWISATA, AKIBAT DAMPAK DARI PANDEMI COVID-19
}

\author{
Irma Dwina \\ Program Studi Pendidikan IPS, FKIP Universitas Lambung Mangkurat \\ irmadewina456@gmail.com
}

\begin{abstract}
ABSTRAK
Perekonomian merupakan sektor terpenting dalam pembangunan ekonomi berkelanjutan pada tatanan nasional. Tinggi rendahnya pendapatan negara pada sektor perekonomian dapat berpengaruh terhadap pembangunan nasional. Sejak awal tahun 2020 dunia digemparkan oleh kehadiran virus covid-19 (Corona virus disease), Covid-19 adalah penyakit menular yang disebabkan oleh virus yang baru di temukan belum lama ini. Kehadiran virus ini mengakibatkan melemahnya aktivitas berbagai sektor perekonomian. Di indonesia sendiri tidak bisa dipungkiri bahwa keadaan ekonomi sangat tidak stabil. Pembatasan sosial berskala besar secara tidak langsung membatasi pelaksanaan aktivitas perekonomian di masyarakat. kehadiran covid-19 ini merubah tatanan kehidupan dalam aspek global maupun nasional. Tulisan ini mengkaji dampak dari pandemi covid-19 terhadap sektor pariwisata di indonesia. Sejak awal maret, menyebarnya virus covid-19 di indonesia membuat aktivitas perekonomian melemah. Menurunnya aktivitas produksi dan distribusi serta menurunnya aktivitas kunjungan tempat wisata lokal di indonesia.
\end{abstract}

Kata Kunci: Ekonomi, Pariwisata, dan Pendemi Covid-19

\section{PENDAHULUAN}

Sejak awal tahun 2020 dunia digemparkan oleh kehadiran wabah virus covid-19. Virus ini berasal dari wuhan, China. Virus Covid-19 ini merupakan virus yang menular. Virus Corona atau severe acut respiratory 2 (Sars-Cov2) Adalah virus yang menyerang sistem pernafasan, sesak nafas, infeksi paru-paru, hingga dapat merenggut nyawa orang yang terinfeksi. Di indonesia sendiri virus covid-19 menyebar mulai dari awal maret 2020. Wabah virus Covid-19 membuat banyak negara ketakutan mengaduk pikiran dan perasaan sejak kasus wuhan yang begitu meningkat (Abbas, 2020). Covid-19 merupakan musuh utama manusia dan mengkhawatirkan dunia karena dapat merenggut nyawa banyak manusia (Abbas, 2020).

Akibat dari Pandemi covid-19 yang berlangsung selama beberapa bulan ini menyebabkan melemahnya aktivitas perekonomian. Aktivitas ekonomi meliputi kegiatan Produksi, distribusi, dan konsumsi (Dini Yuniarti, Bambang Subiyakto, Muhammad Adhitya 
Hidayat Putra, 2020). Produksi adalah kegiatan untuk memproses barang dan jasa yang menciptakan kegunaan. Tujuan adalah untuk memenuhi kebutuhan manusia termasuk kegiatan untuk menciptakan dan menambah kegunaan (Maulidiyah, Bambang Subiyakto, dan Mahmudah Hasanah, 2020)

Berbagai aktivitas perekonomian mulai dari sektor pariwitasa hingga perdagangan terpaksa harus menutup usahanya dan mengurumahkan para karyawannya. Hal ini juga mendukung peraturan pemerintah untuk mennerapkan social distancing. Cara ini tentu memberi dampak langsung terhadap perekonomian bangsa, karena akan banyak pengurangan aktivitas bekerja di luar rumah. Misalnya, berbagai pusat perbelanjaan memutuskan untuk menutup sementara operasionalnya, sehingga pendapatan otomatis menurun. Sejumlah hotel di daerah-daerah wisata seperti Bali, Jakarta, dan Yogyakarta Surabaya ditutup. Pemutusan hubungan kerja (PHK) menjadi langkah efektif bagi perusahaan untuk mengurangi kerugian perusahaan yang semakin bertambah (Syaharuddin, 2020). Hal dilakukan untuk meminimalisir rantai penyebaran wabah virus covid-19.

Padahal aktivitas ekonomi adalah salah satu bentuk upaya manusia dalam konteks pemenuhannya kebutuhan. Karena keberadaan manusia tidak dapat dipisahkan dari sifat alami untuk berusaha mempertahankan dan menjaga kelangsungan hidup. Seringkali pengukuran kesejahteraan hidup manusia diukur dengan standar kepuasan ekonomi yang dapat dicapai melalui kegiatan ekonomi terkandung dalam kegiatan produksi, distribusi, dan konsumsi. Aktivitas ekonomi yang umumnya dilibatkan oleh masyarakat termasuk pertanian, nonpertanian, dan perdagangan layanan, dan layanan (Gunawan, 2014 dalam Abbas, et al 2020). kegiatan konsumsi memiliki tujuan memenuhi kebutuhan hidup termasuk untuk memenuhi kebutuhan jasmani dan rohani. terpaksa harus dihentikan (Dini Yuniarti, Bambang Subiyakto, dan Muhammad Adhitya Hidayat Putra,2020).

\section{PEMBAHASAN}

Sejak menyebarnya wabah covid-19 banyak membuat aktivitas perekonomian dunia terancam melemah. Terlebih negara indonesia. Tidak bisa dipungkiri bahwa keadaan ekonomi indonesia saat ini sangat tidak stabil. Berbagai sektor perekonomian melemah dan terbatas hal tersebut karena adanya pembatasan sosial pada masa pandemi covid-19. Tujuan akhir dari kegiatan ekonomi adalah dalam konteks kesejahteraan dan meningkatkan kualitas hidup. 
(Menurut WHO, 2004 dalam Syaharuddin, Heri Susanto, dan M. Adhitya Hidayat Putra, 2020) kualitas hidup adalah persepsi individu dalam kehidupan mereka dalam konteks konteks budaya, perilaku, dan sistem nilai di mana mereka hidup dan berhubungan dengan standar hidup, harapan, kesenangan, dan penilaian individu posisi mereka dalam hidup. Pengukuran kualitas hidup menurut WHO termasuk kesehatan fisik, kesehatan psikologis, tingkat kebebasan, hubungan sosial, dan hubungan mereka dengan lingkungan hidup (Syaharuddin, Heri Susanto, dan M. Adhitya Hidayat Putra, 2020).

Pariwisata adalah kegiatan perjalanan yang dilakukan oleh seseorang atau sekelompok orang dengan mengunjungi tempat khusus untuk tujuan rekreasi, pengembangan pribadi, atau mempelajari keunikan objek wisata yang dikunjungi dalam periode sementara (Arjana, 2016 dalam Noerkhalishah, Ersis Warmansyah Abbas, dan Melly Agustina Permatasari, 2020). Peranan sektor pariwisata nasional sangat penting sejalan dengan kebijakan pemerintah untuk membangun ekonomi berkelanjutan di masa mendatang. Sektor pariwisata memberikan kontribusi besar terhadap pertumbuhan ekonomi suatu negara. Sektor pariwisata meliputi: tempat rekreasi, hotel, restoran, angkutan serta akselerasi yang mendukung pertumbuhan industri pariwisata lainnya.

Aktivitas lintas sektor pariwisata juga berdampak pada lintas pelaku ekonomi. Seperti penawaran barang dan jasa secara tidak langsung dapat membantu kegiatan ekonomi masyarakat pada sektor lain. Pada masa pandemi covid-19 telah meluluhlantakkan berbagai sektor perekonomian berbagai aktivitas ekonomi terlebih dalam sektor pariwisata terpaksa dihentikan. Sejumlah hotel di daerah-daerah wisata seperti Bali, Jakarta, dan Yogyakarta Surabaya ditutup. Pemutusan hubungan kerja (PHK) menjadi langkah efektif bagi perusahaan untuk mengurangi kerugian perusahaan yang semakin bertambah (Syaharuddin, 2020). Hal ini bertujuan agar tidak terjadi interaksi antar satu dengan lainnya. Interaksi seperti itu mendominasi pandangan jika terjadi benturan kepentingan antara individu dengan kelompok kepentingan. Interaksi sosial hanya terjadi antara para pihak dalam peristiwa reaksi ke dua sisi. Interaksi sosial tidak terjadi jika orang memegang langsung hubungan dengan sesuatu yang tidak mempengaruhi sistem sosial sebagai akibat dari hubungan tersebut. Oleh karena itu Pemerintah menerapkan pembatasan sosial untuk mengurangi interaksi dan campur baur pada masyarakat dalam rangka pemutusan rantai penyebaran covid-19.

Terhitung sejak awal 2020 aktivitas jumlah kunjungan wisatawan menurun. Hal ini dikarenakan banyak negara yang menghentikan penerbangan dan menrepkan lockdown pada 
wilayahnya. Pemberlakuan pembatasan sosial juga berdampak pada aktivitas ekspor dan impor pada negara-negara. Dampak dari wabah covid-19 ini begitu banyak merugikan berbagai pihak pelaku ekonomi. Hal ini menjadi tantangan bagi pemerintah untuk meningkatkan kembali aktivitas roda perekonomian yang sedang melemah. Dengan mengeluarkan beberapa kebijakan seperti New Normal yang akan diterapkan diharapkan dapat menstabilkan keadaan ekonomi kembali.

\section{SIMPULAN}

Kehadiran wabah covid-19 membuat lemah berbagai aktivitas perekonomian. Hal ini berdampak pada pembangunan ekonomi berkelanjutan di masa yang akan datang. Di indonesia pemerintah melakukan berbagai strategi dan kebijakan untuk menstabilkan kembali aktivitas perekonomian. Terlebih pada aktivitas lintas sektor pariwisata juga berdampak pada lintas pelaku ekonomi lainnya. Seperti penawaran barang dan jasa secara tidak langsung dapat membantu kegiatan ekonomi masyarakat melalui sektor pariwisara.. Pada masa pandemi covid-19 telah meluluhlantakkan berbagai sektor perekonomian di berbagai aktivitas ekonomi terlebih dalam sektor pariwisata juga terpaksa harus dihentikan. Melihat peluang dari berbagai sektor khususnya sektor pariwisata berkontribusi besar dalam ekonomi masyarakat. Pengembangan pariwisata ini diharapkan dapat menstabilkan kembali keadaan ekonomi. Hal ini menjadi tantangan bagi pemerintah untuk menggerakkan kembali aktivitas roda perekonomian yang sedang melemah. Dengan mengeluarkan beberapa kebijakan seperti New Normal yang akan diterapkan diharapkan dapat menstabilkan keadaan ekonomi kembali. 


\section{DAFTAR PUSTAKA}

Abbas, E. W., Handy, M. R. N., Shaleh, R. M., \& Hadi, N. T. F. W. (2020). Ecotourism of Martapura River Banjarmasin as a Learning Resources on Social Studies. The Innovation of Social Studies Journal, 1(2), 111-119.

Delima, L., Subiyakto, B., \& Hasanah, M. (2020). Production Activities in Kampung Ketupat, Sungai Baru Banjarmasin. The Kalimantan Social Studies Journal, 1(2), 169-174.

Lestari, J. A., Abbas, E. W., \& Mutiani, M. (2020). Production Activities of Kampung Purun Banjarbaru as a Learning Resource on Social Studies. The Innovation of Social Studies Journal, 1(2), 139-149.

Maulidiyah, M., Subiyakto, B., \& Hasanah, M. (2020). Economic Activities in The Kebun Rambutan Rakyat Sungai Lulut as a Learning Resource on Social Studies. The Kalimantan Social Studies Journal, 1(2), 175-183.

Noerkhalishah, N., Abbas, E. W., \& Permatasari, M. A. (2020). The Utilization of Tourism Education Packages in Amanah Borneo Park as a Learning Resources on Social Studies. The Innovation of Social Studies Journal, 1(2), 158-168.

Norhayati, N., Abbas, E. W., \& Putra, M. A. H. (2019). Social Interaction Pattern Jelai River banks South Basirih. The Innovation of Social Studies Journal, 1(1), 12-20.

Syaharuddin, S., Susanto, H., \& Putra, M. A. H. (2020). Portrait of Community Economic Activities in The River as a Learning Resources on Social Studies With Local CultureBased. The Innovation of Social Studies Journal, 1(2), 178-187.

Syaharuddin, S. (2020). Menimbang Peran Teknologi dan Guru dalam Pembelajaran di Era COVID-19. Menimbang Peran Teknologi dan Guru dalam Pembelajaran di Era COVID-19.

WARMANSYAH ABBAS, E. R. S. I. S. (2020). Menulis di Era Covid-19: Memanage Trauma Psikologis Menghindari Psikosomatis. Menulis di Era Covid-19: Memanage Trauma Psikologis Menghindari Psikosomatis.

Yuniarti, D., Subiyakto, B., \& Putra, M. A. H. (2020). Economic Activities in Kuin Floating Market as a Learning Resource on Social Studies. The Kalimantan Social Studies Journal, 1(2), 130-140. Singkat XII, (4). 